\title{
Multilocus typing for characterization of 'Candidatus Phytoplasma asteris'-related strains in several ornamental species in Italy
}

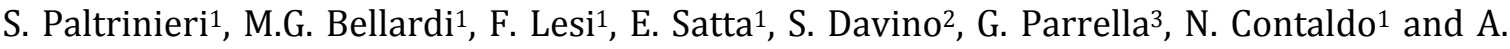 \\ Bertaccini ${ }^{*}$ \\ 1Department of Agricultural Sciences, Plant Pathology, Alma Mater Studiorum-University of Bologna, Italy; \\ ${ }^{2}$ Dipartimento di Scienze Agrarie e Forestali, University of Palermo, Italy; ${ }^{3}$ Institute for Sustainable Plant \\ Protection, CNR, Portici (Napoli), Italy.
}

\begin{abstract}
Different ornamental plants showing symptoms indicating phytoplasma presence were collected between 1993 and 2016 in various floricultural areas in north and south of Italy, including Sicily. These samples were determined to be infected by 'Candidatus Phytoplasma asteris'-related strains, and after PCR/RFLP identification based on the $16 \mathrm{Sr}$ RNA $\backslash$ gene were assigned to the $16 \mathrm{SrI}$-B subgroup. These infected samples were employed for phytoplasma strain differentiation on tuf, groel, $r p$ and amp genes. Phytoplasma strains were from hydrangea, primula, Centaurium erythraea, petunia and gerbera samples showing flower virescence; from gladiolus samples both in vivo and in micropropagation showing the "germs fins" symptomatology, from statice with stunting and lack of flower production, from ranunculus and carnation with virescence and malformation of flowers. All the genes were amplified in nested PCR except the amp gene. For the tuf gene all samples resulted amplified, and Tru1I RFLP analyses confirmed identical profiles with those of 16SrI group phytoplasmas. However, for the other genes only samples from ranunculus, gladiolus in vivo, statice and hydrangea were amplified. For these genes the phytoplasmas were identical to each other and to reference strains belonging to 16SrI-B subgroups; RFLP analyses with Tru1I and AluI further indicated placement in the rpI-B and GroELI-III groups. Considering that these samples have been collected in different Italian regions during 23 years, the relevant conservation in the studied genotypes can perhaps be linked to the presence of common leafhopper vectors, not always identified nor detected in the cultivation areas where the diseased plants were collected. It is important to highlight that ' $\mathrm{Ca}$. P. asteris' is the prevalent phytoplasma reported in flower cultivations worldwide, and its lack of genetic polymorphisms may also indicate a globalized trading of the pathogen together with its propagation material.
\end{abstract}

Keywords: PCR/RFLP analyses, $16 S$ rRNA gene, $r p$ gene, GroEl gene, tuf gene

\section{INTRODUCTION}

Phytoplasmas are bacteria present worldwide in several plant species (Bertaccini et al., 2014), but they are most common and recognized as pathogens in ornamental plants since they dramatically reduce their value as both plants and cut flowers. Symptoms include virescence and phyllody that severely modify the colour, the shape and the behaviour of infected plants. Among the different phytoplasmas those affiliated with 16SrI-B ('Candidatus

*Email: assunta.bertaccini@unibo.it 
Phytoplasma asteris' commonly known also as aster yellows phytoplasma) (Lee et al., 2004) are most reported in ornamental plants. Therefore, in a period of 23 years (1993-2016) a study was undertaken in a number of diverse species reported to be infected by this phytoplasma in diverse geographic areas of Italy.

The purpose of this study was to verify the possible presence of genetic variability in the 16SrI-B phytoplasmas in Italy by using a multilocus typing approach on genes other than the $16 S r R N A$, that is employed for general phytoplasma classification. This characterization could be helpful in epidemiologic studies aimed to reduce the impact of phytoplasma diseases and to verify their transmission pathways in Italy.

\section{MATERIALS AND METHODS}

\section{Samples}

Samples from different ornamental plant species showing symptoms indicating phytoplasma presence were collected between 1993 and 2016 in various floricultural areas in north and south Italy. In particular, the 23 phytoplasma strains employed were from hydrangea (Hydrangea macrophylla L.) (5), Primula spp. (3), Centaurium erythraea (2), Petunia spp. (2) and gerbera (Gerbera jamesonii L.) (1) samples showing flower virescence; from Gladiolus spp. samples both in vivo and in micropropagation (2) showing the "germs fins" symptomatology; from statice (Limonium sinuatum L.) (2) with stunting and lack of flower production collected in a greenhouse located in Sicily (Southern Italy) (Figure 1); from Ranunculus asiaticus L. (2) and carnation (Dianthus barbatus L.) (4) with virescence and flower malformation.
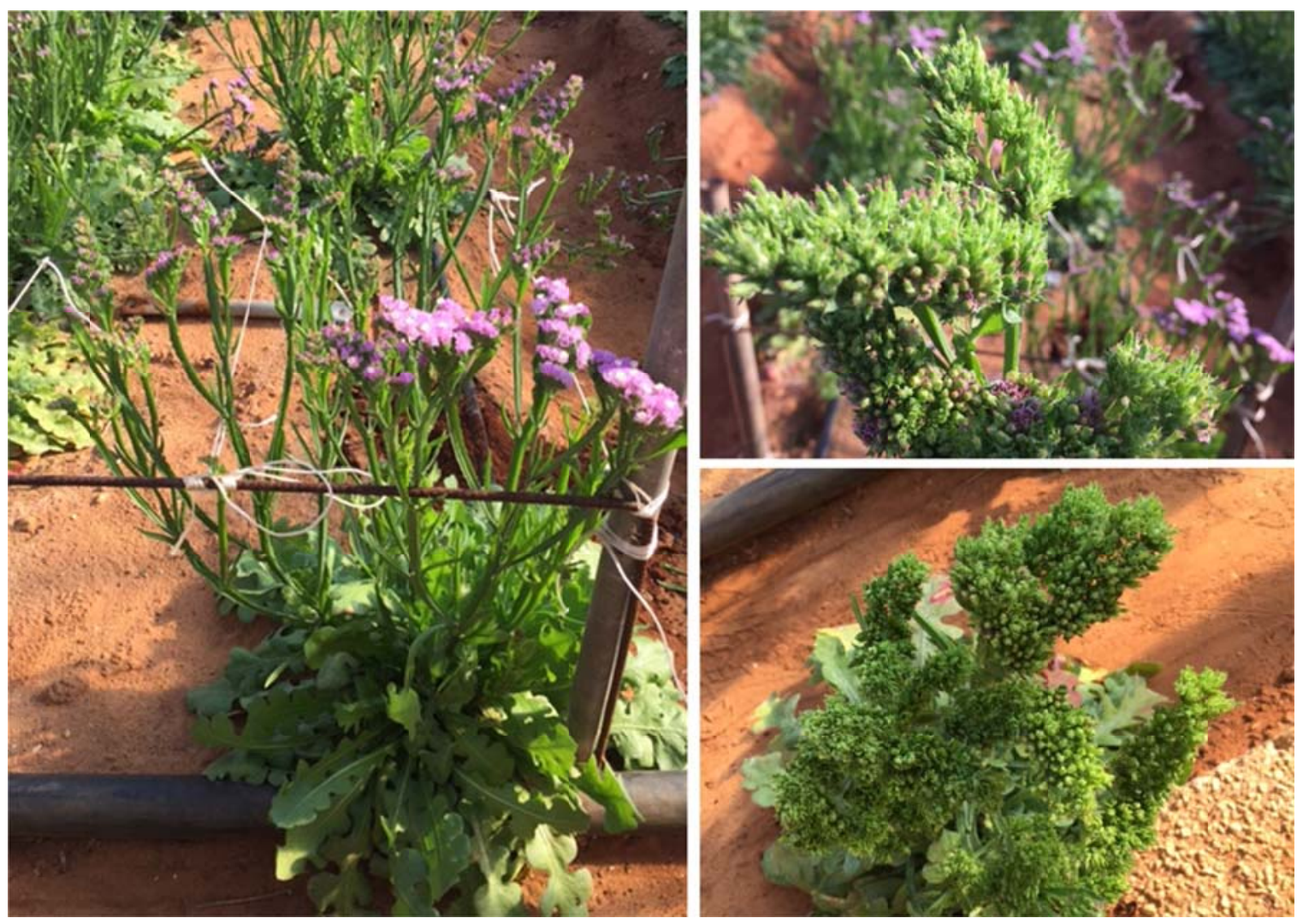

Figure 1. L. sinuatum plants in greenhouse showing symptoms of lack of flower, stunting and malformation due to the presence of aster yellows phytoplasmas (16SrI-B). 


\section{Phytoplasma detection and ribosomal subgroup identification}

Nucleic acid extraction from frozen or fresh samples used a chloroform/phenol extraction (Prince et al., 1993) followed by nested-PCR analyses with previously reported procedures (Duduk et al., 2013). In particular, for samples in which the phytoplasma detection is reported here for the first time (Table 2), direct PCR assays used $20 \mathrm{ng}$ of template DNA with primers R16F2n/R2 (Gundersen and Lee, 1996) followed by primers R16(I)F1/R1 (Lee et al., 1994) in nested PCR assays, using amplicons diluted 1:30 with sterile distilled water as template was used. A tube with reaction mixture devoid of DNA template was included as negative control in each PCR reaction. PCR amplifications were performed following reported parameters (Schaff et al., 1992) and products were electrophoresed in $1.0 \%$ agarose gel; the gel was stained with ethidium bromide and visualised under UV light. RFLP analyses with Tru1I and HhaI (Fermentas, Vilnius, Lithuania) restriction enzymes following the manufacturer's instructions were then carried out on positive samples; the RFLP products were separated by electrophoresis in $6.7 \%$ polyacrylamide gels, and visualised with an UV transilluminator.

\section{Multilocus RFLP characterization}

Amplification of the samples with direct or nested PCR yielded positive results after amplification of the $16 S$ rRNA gene was carried on tuf gene amplifying primers (Makarova et al. 2012) and on groel and $r p$ genes in nested PCR with primer combinations reported in Table 1. The amplification of $a m p$ gene was achieved in direct PCR with primers listed in Table 1. Amplicons of the expected length amplified from samples and reference strains NJAY (New Jersey aster yellows, 16SrI-A), AY-J (aster yellows from France, 16SrI-B) and AY-27 (aster yellows from Canada, 16SrI-B) from the micropropagated phytoplasma collection (Bertaccini, 2015) were obtained using the amplification conditions reported in the respective literature (Table 1). They were then examined by RFLP analyses as reported above with selected informative enzymes and restriction profiles were compared with those available in the literature.

Table 1. Primers and primer combination employed for the multilocus analyses of phytoplasma molecular diversity.

\begin{tabular}{|c|c|c|c|}
\hline \multicolumn{4}{|c|}{ Direct PCR } \\
\hline Gene & Primer & Sequence 5'-3' & Literature \\
\hline & rpF1 & GGACATAAGTTAGGTGAATTT & Lim and Sears, \\
\hline$r p$ & rpR1 & ACGATATTTAGTTCTTTTTGG & 1992 \\
\hline & Amp-N1 & AAGAATTCCATATGCAAAATCAAAAAACTCA & Kakizawa et al., \\
\hline amp & Amp-C1 & AAGAGCTCGAGTTATTTATTGTTTTTGTTTTTTTTAAC & 2004 \\
\hline & AYgroelF & GGCAAAGAAGCAAGAAAAG & Mitrović \\
\hline groEL & AYgroelR & TTTAAGGGTTGTAAAAGTTG & 2011 \\
\hline \multicolumn{4}{|c|}{ Nested PCR } \\
\hline$r p$ & $\begin{array}{l}\operatorname{rp}(\mathrm{I}) \mathrm{F} 1 \mathrm{~A} \\
\operatorname{rp}(\mathrm{I}) \mathrm{R} 1 \mathrm{~A}\end{array}$ & $\begin{array}{l}\text { TTTTCCCCTACACGTACTTA } \\
\text { GTTCTTTTTGGCATTAACAT }\end{array}$ & Lee et al., 2004 \\
\hline groEL & $\begin{array}{l}\text { AYgroesF } \\
\text { AYampR }\end{array}$ & $\begin{array}{l}\text { ATCAGAAAAAGAAAAATCCT } \\
\text { GCAACAGCAGCAAATAAAAC }\end{array}$ & $\begin{array}{l}\text { Mitrović et al., } \\
2011 \mathrm{a}\end{array}$ \\
\hline
\end{tabular}

\section{RESULTS AND DISCUSSION}

All samples in this study were determined to be infected by aster yellows strains that after PCR/RFLP analyses on $16 S$ rRNA gene were assigned to 16SrI-B subgroup (Table 2). All 
23 samples also were positive after amplification of tuf gene, and yielded identical RFLP results for this gene (data not shown). However, only some of the tested species were positive for amplification of the other genes (Table 2). In particular, samples of statice, gladiolus, ranunculus and hydrangea were amplified with $a m p, r p$ and groEl gene primers, whereas primula samples were only amplified with groEl gene primers. In contrast, samples of $C$. erythraea and D. barbatus were only amplified with primers for the $r p$ gene. Results from primers for the other genes do not appear related to the year of collection (storage time) nor to the diversity of phytoplasmas in the other amplified genes. RFLP analyses show that no differences were present among the detected strains allowing to group all the studied aster yellows strains into the same multilocus type cluster (Figure 2). Overall the obtained profiles demonstrate high genetic RFLP homogeneity among all the strains studied. RFLP results were indistinguishable among all samples in this study and the reference strain AY-27 in periwinkle originally collected in field infected samples in Canada.
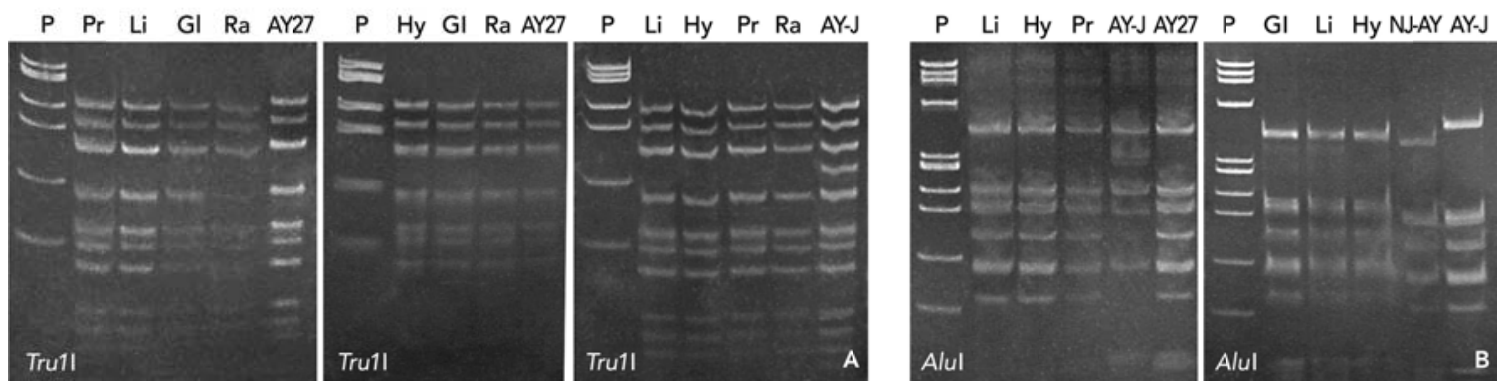

Figure 2. RFLP analyses on $6.7 \%$ polyacrylamide gels of groel gene amplicons obtained after nested-PCR on some of the samples analyzed. The restriction enzymes used are indicated at the bottom. Acronyms of samples: Pr, Primula spp.; Li, L. sinuatum; Gl, Gladiolus spp.; Ra, Ranunculus spp., Hy, Hydrangea spp. Reference strains AY27, aster yellows from lettuce from Canada; AY-J, aster yellows from France; and NJAY, New Jersey aster yellows. In A marker P, phiX174 HaelII-digested with fragment sizes, from top to bottom, of $310,281,271,234,194,118$ and 72 bp in B marker P, marker phiX174 HaeIII-digested with fragment sizes, from top to bottom, of 1353, 1078, 872, 603, 310, 281, 271, 234, 194, 118 and $72 \mathrm{bp}$.

However, the RFLP characterizations carried out on the amp gene by Tru1I allowed to determine that the profiles of all samples collected in Italy were identical to each other, but were different from all the reference strains used. Considering that the strains positive on this gene (statice, hydrangea, gladiolus and ranunculus) were collected in different regions of Italy i.e Sicily, Campania, Tuscany and Liguria, respectively, and over more than 20 years, some epidemiologic considerations are suggested. The phytoplasma membrane proteins have important roles in the attachment to the host cell, and amp coded proteins were suggested as candidates for involvement in host-phytoplasma interactions; considering their high expression especially in aster yellows phytoplasmas (Kakizawa et al., 2004) they may also determine insect specificity (Suzuki et al., 2006). Phytoplasmas" amp localized in the microfilaments of the insect's intestine in aster yellows (strain OY) was shown in literature to form a complex with insect proteins actin and myosin. In addition, the formation of amp-microfilament complexes was correlated with the phytoplasmatransmission capability of leafhoppers, suggesting that the interaction plays a major role in determining the transmissibility of phytoplasmas (Suzuki et al., 2006). The finding of no variability in this gene in the Italian samples indicates that there was very little phytoplasma 
interaction with the environment including insect vectors. Considering the limited information available on insect vectors of phytoplasmas infecting ornamental plants in Italy and also worldwide, there is only a recent report of presence of aster yellows in Laodelfax striatellus detected on aster yellows infected hydrangeas (Bertaccini et al., 2015), it is very likely that the vegetative propagation of ornamental material could play an important role in maintaining the genetic homogeneity detected in the studied samples.

Table 2. Results of PCR/RFLP characterization on different genes for the ornamental plant samples studied and reference phytoplasma strains.

\begin{tabular}{|c|c|c|c|c|c|c|c|}
\hline Plant species tested & $\begin{array}{c}\text { Year } \\
\text { samplings }\end{array}$ & $\begin{array}{c}16 S \text { rRNA } \\
\text { subgroup* }\end{array}$ & $\begin{array}{c}\text { tuf } \\
\text { gene*** }\end{array}$ & $\begin{array}{c}r p \\
\text { gene§ }\end{array}$ & $\underset{\text { gene }^{\circ}}{\operatorname{amp}}$ & $\begin{array}{l}\text { groEL } \\
\text { gene }^{\circ \circ}\end{array}$ & Literature \\
\hline Limonium sinuatum & 2015 & $\mathrm{I}-\mathrm{B}$ & AY & B & Ita & III & This work \\
\hline Hydrangea macrophylla & 2014 & $\mathrm{I}-\mathrm{B}$ & AY & B & Ita & III & This work \\
\hline Primula spp. & 1998 & $\mathrm{I}-\mathrm{B}$ & AY & $\mathrm{Nd}$ & $\mathrm{Nd}$ & III & This work \\
\hline Centaurium erythraea & 1998 & $\mathrm{I}-\mathrm{B}$ & AY & B & $\mathrm{Nd}$ & $\mathrm{Nd}$ & $\begin{array}{c}\text { Contaldo et } \\
\text { al., } 2010\end{array}$ \\
\hline Petunia spp. & 1998 & $\mathrm{I}-\mathrm{B}$ & AY & $\mathrm{Nd}$ & $\mathrm{Nd}$ & $\mathrm{Nd}$ & This work \\
\hline Dianthus barbatus & 1996 & $\mathrm{I}-\mathrm{B}$ & AY & B & $\mathrm{Nd}$ & $\mathrm{Nd}$ & This work \\
\hline Gerbera jamesonii & 1996 & $\mathrm{I}-\mathrm{B}$ & AY & Nd & $\mathrm{Nd}$ & $\mathrm{Nd}$ & $\begin{array}{c}\text { Bertaccini e } \\
\text { Bellardi, } \\
1998\end{array}$ \\
\hline Gladiolus spp. & 1993 & $\mathrm{I}-\mathrm{B}$ & AY & $\mathrm{Nd}$ & Ita & III & $\begin{array}{l}\text { Bertaccini } \\
\text { et al., } 1992\end{array}$ \\
\hline Ranunculus asiaticus & 1993 & $\mathrm{I}-\mathrm{B}$ & AY & B & Ita & III & $\begin{array}{l}\text { Bertaccini } \\
\text { et al. } 1993\end{array}$ \\
\hline NJ-AY & $\begin{array}{c}\text { From } \\
\text { collection }\end{array}$ & $\mathrm{I}-\mathrm{A}$ & AY & A & Usa & I & $\begin{array}{c}\text { Lee et al., } \\
1998\end{array}$ \\
\hline AY-J & $\begin{array}{c}\text { From } \\
\text { collection }\end{array}$ & $\mathrm{I}-\mathrm{B}$ & AY & $\mathrm{Nt}$ & $\mathrm{Fr}$ & IV & $\begin{array}{l}\text { Mitrović et } \\
\text { al., } 2011\end{array}$ \\
\hline AY-27 & $\begin{array}{c}\text { From } \\
\text { collection }\end{array}$ & I-B & AY & $\mathrm{Nt}$ & Can & III & This work \\
\hline
\end{tabular}

*, ribosomal subgroups are reported by Lee et al. (1998); ${ }^{* *}, \mathrm{AY}$, tuf gene profile referable to aster yellows; §, identical letter correspond to identical RFLP profile, ${ }^{* *}$, Ita=Italy; Usa=United States of America; $\mathrm{Fr}=$ France; $\mathrm{Can}=\mathrm{Canada} ;{ }^{\circ \circ}$, roman numbers correspond to different profiles as reported in Mitrović et al., 2011. Nd, not determined.

\section{CONCLUSIONS}

The results of this research shows that there is a tremendous need for further study of epidemiology of phytoplasma diseases in ornamental plants, especially considering the continuous increase of new symptomatic species (Davino et al., 2007; Paltrinieri et al., 2015). The 16SrI-B phytoplasmas identified in several ornamental plants in Italy were also detected in Laodelfax striatellus on hydrangea with virescence (Bertaccini et al., 2015), but no further information is available on insect vectors of these phytoplasmas in the different 
environments in which the infected samples were collected. It is also possible to hypothesize that given the genetic homogeneity of detected strains over two decades, the main mode of transmission is the vegetative propagation of asymptomatic infected materials. However, it is also possible that in some cases seed transmission could have a role in the epidemiology of these diseases as reported for other phytoplasma associated diseases (Calari et al., 2011, Satta et al., 2016). More investigations are needed and some are in progress (Contaldo et al., 2012; 2016) to increase the epidemiologic knowledge about these diseases and propose adequate management measures towards reducing the risk of severe losses due to epidemic outbreaks.

\section{Literature cited}

Bertaccini, A., Bellardi, M.G., Vibio, M., Lee, I-M., and Davis, R.E. (1992). Detection of mycoplasmalike organisms in gladiolus using microscopy and DNA-probes. Acta Hortic. 325, 703-708.

Bertaccini, A., Vibio, M., Bellardi, M.G., and Lee, I-M. (1993). Characterization of mycoplasmalike organisms associated with Italian gladiolus and hydrangea crops. 6th Int. Congr. Plant Pathol., July 28/August 6, Montreal, Canada, abs. n. 1.2.2, 34.

Bertaccini, A., and Bellardi, M.G. (1998). La virescenza del fiore. "Gerbera”, Supplemento a Colture protette 12, $39-42$.

Bertaccini, A., Duduk, B., Paltrinieri, S., and Contaldo, N. (2014). Phytoplasmas and phytoplasma diseases: a severe threat to agriculture. Am. J. Pl. Scieences 5, 1763-1788.

Bertaccini, A., Paltrinieri, S., Contaldo, N., Mori, N., Cavicchi, L., and Bellardi, M.G. (2015). Severe diseases induced by viruses and phytoplasmas in Hydrangea in Italy. Acta Hortic. 1072, 105-112.

Bertaccini, A. (2015). Phytoplasma Collection, http://ipwgnet.org/collection.

Calari, A., Paltrinieri, S., Contaldo, N., Sakalieva, D., Mori, N., Duduk, B., and Bertaccini, A. (2011). Molecular evidence of phytoplasmas in winter oilseed rape, tomato and corn seedlings. Bull. Insectol. 64(Suppl.), S157S158.

Contaldo, N., Paltrinieri, S., Bertaccini, A., and Bellardi, M.G. (2010). Individuazione del fitoplasma del giallume dell'astro in Centaurea erythraea Rafn. Petria 20(3), 708-709.

Contaldo, N., Bertaccini, A., Paltrinieri, S., Windsor, H.M. and Windsor, D.G. (2012). Axenic culture of plant pathogenic phytoplasmas. Phytopath. Medit. 51, 607-617.

Contaldo, N., Satta, E., Zambon, Y., Paltrinieri, S., Bertaccini, A. (2016). Development and evaluation of different complex media for phytoplasma isolation and growth. J. Microbiol. Meth. 127, 105-110.

Davino, S., Calari, A., Davino, M., Tessitori, M., Bertaccini, A., and Bellardi, M.G. (2007). Virescence of tenweeks stock associated to phytoplasma infection in Sicily. Bull. Insectol. 60(2), 279-280.

Duduk, B., Paltrinieri, S., Lee, I-M., and Bertaccini, A. (2013). Nested PCR and RFLP analysis based on the 16S rRNA gene. Meth. in Mol. Biol. 938, 159-171.

Gundersen, D.E., and Lee I-M. (1996). Ultrasensitive detection of phytoplasmas by nested-PCR assays using two universal primer pairs. Phytopath. Medit. 35, 144-151.

Kakizawa, S., Oshima, K., Nishigawa, H., Jung, H.Y., Wei, W., Suzuki, S., Tanaka, M., Miyata, S.I., Ugaki, M., and Namba, S. (2004). Secretion of immunodominant membrane protein from onion yellows phytoplasma through the Sec protein-translocation system in Escherichia coli. Microbiology 150, 135-142.

Lee, I-M., Gundersen, D.E., Hammond, R.D., and Davis, R.E. (1994). Use of mycoplasma-like organism (MLOs) group specific oligonucleotide primers for nested-pcr assays to detect mixed-MLO infections in a single host plant. Phytopathology 84, 559-566. 
Lee, I-M., Gundersen-Rindal, DE., Davis, RE., and Bartoszyk, IM. (1998). Revised classification scheme of phytoplasmas based on RFLP analyses of 16S rRNA and ribosomal protein gene sequences. Int. J. Syst. Bacteriol. $48,1153-1169$.

Lee, I-M., Gundersen-Rindal, D.E., Davis, R.E., Bottner, K.D., Marcone, C. and Seemüller E. (2004). 'Candidatus Phytoplasma asteris', a novel phytoplasma taxon associated with aster yellows and related diseases. Int. J. Syst. Evol. Microbiol. 54, 1037-1048.

Lim, P.O., and Sears, B.B. (1991). The genome size of a plant-pathogenic mycoplasma-like organism resembles those of animal mycoplasmas. J. Bacteriol. 173, 128-2830.

Makarova, O., Contaldo, N., Paltrinieri, S., Kawube, G., and Bertaccini, A. (2012). DNA barcoding for identification of 'Candidatus Phytoplasmas' using a fragment of the elongation factor tu gene. PLoS ONE 7(12), 1-9.

Mitrović, J., Kakizawa, B., Duduk, B., Oshima, K., Namba, S., and Bertaccini, A. (2011). The groEL gene as an additional marker for finer differentiation of ' Candidatus Phytoplasma asteris'related strains. Ann. Appl. Biol. $159,41-48$.

Mitrović, J., Contaldo, N., Paltrinieri, S., Mejia, J.F., Mori, N., Bertaccini, A., and Duduk, B. (2011a). The use of groEL gene for characterisation of aster yellows phytoplasmas in field collected samples. Bull. Insectol. 64(Suppl), S17S18.

Paltrinieri, S., Contaldo, N., Bertaccini, A., Cavicchi, L., and Bellardi, M.G.. (2015). First report of phytoplasmas associated with Erysimum linifolium L. stunting. Acta Hortic. 1072, 117-122.

Prince, J.P., Davis, R.E., Wolf, T.K., Lee, I-M., Mogen, B.D., Dally, E.L., Bertaccini, A., Credi, R., and Barba, M. (1993). Molecular detection of diverse mycoplasma-like organisms (MLOs) associated with grapevine yellows and their classification with aster yellows, X-disease, and elm yellows MLOs. Phytopathology 83, 1130-1137.

Satta, E., Contaldo, N., Paltrinieri, S., and Bertaccini, A. (2016). Biological and molecular proof of phytoplasma seed transmission in corn. IOM2016 - 21 $1^{\text {th }}$ Congr. Intern. Org. Mycoplasmology, Brisbane, Australia, July 3-7, 61, 65-66.

Schaff, D.A., Lee, I-M., and Davis, R.E., (1992). Sensitive detection and identification of mycoplasmalike organisms by polymerase chain reactions. Biochem. Biophys. Res. Comm. 186, 1503-1509.

Suzuki, S., Oshima, K., Kakizawa, S., Arashida, R., Jung, H.Y., Yamaji, Y., Nishigawa, H., Ugaki, M., and Namba, S. (2006). Interaction between the membrane protein of a pathogen and insect microfilament complex determines insect-vector specificity. Proc. Natl. Acad. Sci. USA 103, 4252-4257. 